\title{
Community Empowerment and their Support for Tourism Development: an Inquiry based on Resident Empowerment through Tourism Scale
}

\author{
Ruwan Ranasinghe \\ Uva Wellassa University, Sri Lanka \\ Jayathree Pradeepamali \\ Uva Wellassa University, Sri Lanka
}

Received: 29 May 2018. Revision received: 4 October 2019. Accepted: 23 October 2019

\begin{abstract}
Sustaining residents' support is critical for successful destinations. Though empowerment is decisive in attitude, quantitative researches show a dearth. This study uses resident empowerment through tourism scale to model empowerment's role in sustaining residents support for tourism in the light of Social Exchange Theory (SET) and Weber's theory of Formal and Substantive Rationality (WFSR), aiming at identifying the impacts of residence community empowerment as a pivot in advocating residents' support for tourism development. Kalpitiya, a fast developing tourist destination in the Island was found a fertile ground to test the proposed model. A random sample of 619 was used to collect primary data through a self-administered questionnaire. Data were analyzed using Structural Equation Model approach in SmartPLS3. Findings show that residents are influenced by personal economic benefits and pride, self-esteem heightened by psychological empowerment. Political empowerment influenced on positive impacts leading to residents' support for tourism development. The paper argues that SET merely insufficient to explain residents' behavior towards tourism while WFSR appears as a broader approach. Tourism practitioners need the attention towards non-economic considerations such as values, believes and morals in advocating residents' support for tourism since economic gains can't assure it alone.
\end{abstract}

Keywords: Community Empowerment, Tourism Impacts, Residents' Support for Tourism, Resident Empowerment through Tourism Scale (RETS), Kalpitiya

JEL Classification: M5, M21, M140

\section{Introduction}

Advocating the support and involvement of wide range of stakeholders is a prerequisite for successful tourist destination development in which resident community is a significant component in it (Boley, Ayscue, Maruyama, \& Woosnam, 2016). As stated by Andereck and Nyaupane (2011 as cited in Boley, McGehee, Perdue and Long, 2014). Local residents of a tourist destination are a core source of tourist service suppliers who provide accommodation, information, facilities, and services been a focal point in the tourism development process in a destination. The resident community is 
defined by Brehm, Eusaneheauar, and Kranich (2004) as a "group of individuals living or working within the same geographic of residence". They have to be the first ladder of destination development. As stated by Nunkoo and Ramkisson sustainable tourist destination development is achievable through effective involvement of local residents and accommodating their opinions in the development initiatives. (Boley \& McGehee, 2014) The prior will guide the next stages to reach its goals as the core of a destination development project.

Their involvement and participation in tourism will basically depend on what they could receive and what they would sacrifice through this link and enrollment of tourism within their residence. Mostly the resident's livelihoods which depend on tourism will result in them to analyze economic and non-economic costs and benefits they grant through tourism impacts and depend on that they determine to support or oppose tourism development. "Research conducted in this field is considered important because understanding the reasons why the residents do or do not support the tourism industry and its growth will help to establish models for such developments that minimize the negative impacts and maximize the support for these initiatives" (VargasSachez, Porras-Bueno, \& Plaza-Mejiha, 2011). So to enable them in this wider context of tourism, if to achieve its strategic outcome in long path development projects these residents who depend on the benefits and deteriorate through the cost has to be empowered only with the positive influence of this development projects, Resident involvement has to be initiated through the impacts of empowerment in the field itself. "Empowerment leads individuals to revel and enhance in their control and mastery over themselves on factors and decisions which sharpen their livelihood" (Hur, 2006). That deside residents to support or oppose tourism development in a particular region while contributing to attaining tourism development in the broad sense of sustainability. Accordingly, empowerment will influence the resident's perception to support tourism as a construct of its impacts" (Gursoy, Jurowski, \& Uysal, 2002). Equally, (Cole, 2006) and (Hidayat, Rahmanita, \& Hermantoro, 2017) recognizes community empowerment as one of the significant components that lead to community participation in tourism development. He further elaborates that "members of a community are active agents of change and they have the ability to find solutions to their problems, make decisions, implement actions and evaluate their solutions". However, when examining the previous literature, in identifying the relationship between empowerment and its influence on residents in other constructs like supporting tourism, more researchers have basically utilized social exchange theory to examine the facts.

Social Exchange Theory (SET) has successfully been used to explain resident's attitudes and perceptions on tourism in reserches done by Perdue, long and Allen 1990. Nevertheless, over the time, limitations of SET were identified by Boley and McGehee in 2014 that initiated only the economic benefits and its relationship on tourism impacts. The application of RETS (Resident Empowerment through Tourism Scale) model in a rural context and in an island county like Sri Lanka is another gap to be identified since its reliability on international context still to be confirmed by its applicability in different cultural and geographical settings in the world. (Boley, Nickerson, \& Bosak, 2011; Woosnam \& Norman, 2010), only a limited number of papers have been done in advancing scale development process to greater heights by evaluating the validity of these measures developed, like, (Hosany, Prayag, Deesilatham, Cau service, \& Odeh, 2014; Kim \& Ritchie, 2014; Sirakaya-Turk, Ekinci, \& Kaya, 2007). The above undermines the validity of measures used in the literature to measure community empowering. (Boley, McGehee, Perdue, \& Long, 2014) 
Primarily, this study aims at identifying the impacts of residence community empowerment as a pivot in advocating residents' support for tourism development. Additionally, the study focuses at analyzing the measurement of resident community empowerment, identifying the relationship between empowerment and tourism impacts, and analyzing how the impacts lead to shape community response to support tourism development. The study expects to guide and assist, the key tourism decision-makers and planners to effectively achieve their tourism strategic goals. This study which deals with residents empowerment and their overall perception on supporting tourism, been a part of resident attitude research presents its significance, both contributing to theoretical and practical requirements in the field. So this study will enable to measure reliability and applicability of RETS in Sri Lanka in developing Kalpitiya tourism zones for destination developments.

Theoretically, this study will prove the use of theories and their influence, bringing economic and non-economic factors into its dimensions, explaining and supporting already developed frameworks under theories. The study applies RETS as an antecedent in measuring psychological, social, and political empowerments of residents which has been only a limited factor in previous researchers focused only on costbenefit analysis of residents support for tourism. The study focuses on the identification of the key constructs, rational and substantive which grounded on theories related and developments of models like RETS in depicting their true relations and strength in predicting residents' support for tourism development. Accordingly, the role of empowerment as non-economic factors along with the economic factors that contribute in deciding a resident to support tourism development in a particular tourism zone that would initially affect the destination development has to be measured and examined in an emerging destination like Kalpitiya.

\section{Literature Review and Hypotheses Development}

\subsection{Resident Community Involvement in Tourism}

The resident community at a tourist destination is one of the vulnerable stakeholder since any impact generated from tourism is influential on them irrespective of their adversity or privilege (Choi \& Murray, 2010). As stated by (Dogans \& Denny, 2004) preservation of local cultural values, as well as erosion of local cultural values both, could occur due to tourism and related activities. Moreover, "virtually all of the negative impacts (of tourism) can be avoided when communities take the responsibility for guiding tourism growth in the directions best suited to the local situation" (Gunn, 1979).

To attain these core directions residents have to be identified as the ladder of its success since they are the key influencing group in a destination. According to Belisle and Hoy (1980) residents of a destination reserve the decisive command of pausing tourism development. Moreover, they argue that in order to make tourists welcome and to make tourist experience a complete one. Also, their strength is examined by researchers as "if residents resent or fear tourism, their resistance and hostility can destroy the local industry's potential" confirming the fact that residents are an essential component of whole tourism process (Boley, Maruyama, \& Woosnam,2015). 


\subsection{Residents' Attitudes on Tourism}

(Gursoy, Chi, \& Dyer, 2010) explain that tourism's impacts can better be explained through residents' perspectives on it. Similarly, resident attitudes on tourism and how to advocate their support for tourism has become one of the unanswered questions of tourism thesis. Consequently, residents' perceptions on tourism that shape their attitudes can be used as a predictor of residents' ultimate response towards tourism which may be either to support it or to oppose it (Boley, McGehee, Perdue, \& Long, 2014). To succeed in tourism development, the enrollment and the attitude in their decision on supporting or opposing is essential in examining the previous and present status in resident attitude research. It is revealed that, over the decades, the field of researchers on resident attitude toward tourism has been the base in tourism literature according to (Boley \& Perdue, 2012), while, (McGehee \& Andereck, 2004) examines the significance of it as "the most systematic and wellstudied area of tourism".

\subsection{Social Exchange Theory (SET)}

SET postulates that social interaction (or support for tourism in the above case) is an exchange based on the individual's perceived rewards and costs of the relationship as stated by (Homans in 1958). Ap (1992) examines SET can act as a framework to understand local residents' attitudes on tourism, since, it is a coherent "theoretic framework, which can account for both the positive and negative impacts of tourism as perceived by the host community, logically and intuitively appealing one that may be used, to explain why residents develop positive or negative perceptions of tourism impacts". In explaining SET from the perspective of local residents attitude on tourism, "the perceived benefits of exchanges from tourism will guide the residents overall attitude toward tourism" as mentioned by Ap 1992 and the first study carried to do an empirical test, for the principles of social exchange theory, in determining residents attitude toward tourism development was laid by Perdue et al in 1990. (Boley, McGehee, Perdue, \& Long, 2014) and (Boley \& McGehee,2014)

SET in tourism context creates residents to be the rational actors, who always seek "to maximize their gains" (Cohen, 1967) accordingly, the proposition of "if residents perceive tourism positively they will support tourism while if they perceive tourism negatively they will oppose tourism development" (Choi \& Sirakaya, 2005). Consequently, previous studies postulate and it is evident in literature that the residents' favorable or unfavorable perception on tourism and related activities strongly related with their perceived support or oppose for tourism in their territories. Based on the above account it can be stated that;

- $\mathrm{H}_{1}$ - Perceived positive impact of tourism is positively related with residents support for tourism.

- $\mathrm{H}_{2}$ - Perceived negative impact of tourism is negatively related with residents support for tourism.

\subsection{Weber's theory of formal and substantive rationality (WFSR)}


Max Weber an early advocate of sociology is considered to be the proponent of WFSR. The theory's suitability in researching individual attitudes is rationalized since it consists both economic and non-economic variable such as values, believes and morals. Thus, the theory has extensively been applied in researching human economic transactions and its ancestries as proposed by Andereck et al, (2005).

When, (Kalberg, 1980) explains that treating human rationality is being only driven by economic gain (McGehee 2007), illustrates that economic rationalization of individuals has formal or substantive stance while emotional factors are influential in such rationalizations. Further, it is evident in literature that substantive rationality as being guided by values and attitudes an individual possess. Thus, the potential decisions of individuals on negative impacts indicate negative suppositions and viz-a-viz. SET theory was embraced by formal rationality in WFSR, constructing measures to identify resident's perceptions of personally benefiting from tourism as argued by Boley (2014). Although it is, it doesn't carry a version of economic connotation. So, Boley, through his studies in 2014 added clarity to the constructs adapting, "personal benefits from Tourism" to "personal economic benefit from tourism" by providing a rationalized measures to be tested in models in resident attitude research. Successively, significant number of researches have been conducted to test the relationship between direct economic gains from tourism and residents' support for tourism and related activities (McGehee \& Andereck, 2004). Thus, individual benefits pertaining to economic gains from tourism believed to become a significant predictor of resident perception of tourism impacts for residents' support for tourism and related development in their areas. Thus, it can be postulated that:

- $\mathrm{H}_{3}$ - Perceived economic benefits from tourism are negatively related with perceived negative impacts of tourism

- $\mathrm{H}_{4}$ - Perceived economic benefits from tourism are positively related with perceived positive impacts of tourism

- $\mathrm{H}_{5}$ - Residents' support for tourism is positively related with perceived economic benefits from tourism

\subsection{Psychological Empowerment "Resident Empowerment through Tourism Scale (model)"}

According to Friedmann, (1992) Psychological empowerment of an individual is linked to one's self-esteem and one's "sense of potency". According to Cattaneo and Chapman, (2010) and the general acceptance in psychology, an individual's level of participation is strongly linked to his psychological empowerment. In tourism's context, psychological empowerment is referred to the capability of uplifting residents' sense of pride in their living environment and their cultural identity. Although this influence has to be further operationalized as a construct to predict resident attitude towards tourism, the previous literature findings like (Besculides, Lee \& McCormick, 2002; Woosnam, Norman, and Ying, 2009) lead to believe psychological empowerment will generate a positive influence on resident perception. Boley, McGehee, Perdue \& Long, (2014) and Zimmerman (1995) describe psychological empowerment have to be included as an antecedent to resident attitude toward tourism, since it benefits residents to receive from tourism that would increase their pride and self-esteem, while also, that has to be hypothesized, to illustrate the direct impact on resident perceptions of tourism's benefits and costs, as well as their overall support for tourism. 
- $\mathrm{H}_{6}$ - Residents' Perceived psychological empowerment is negatively related with perceived negative impacts from tourism

- $\mathrm{H}_{7}$ - Residents' Perceived psychological empowerment is positively related to perceived positive impacts from tourism

- $\mathrm{H}_{8}$ - Residents' Perceived psychological empowerment is positively related to their intention to support for tourism

\subsection{Social Empowerment "Resident Empowerment through Tourism Scale (model)"}

Kay (2006), describes the base of social empowerment as "the emphasis on cohesion and collaboration are believed to be essential requirements for local economic development", while (Di Castri, 2004) sees it as "having an important role in helping bring people together to work on common interests" (cited in Boley, 2012). Social empowerment can be improved by strengthening the relationships of local residents and other tourism related stakeholders. Such efforts also result in promoting community cohesion that is linked with building strong networks for individuals (Scheyvens, 1999). Once, the residents feel that they are socially linked and related to other important stakeholders they prompt to participate actively in the activities of their concern and this notion is common for tourism as well. Thus, only socially empowered individuals and groups can work together to build local tourism, benefiting them while supporting local community. Boley et al. (2014) emphasize that "It is believed the increased cohesion and collaboration associated with social empowerment will have a significant, impact upon how residents interpret tourism's impacts, as well as their overall support for tourism". It is hypothesized as;

- $\mathrm{H}_{9}$ - Perceived social empowerment of individuals negatively related to perceived negative tourism impacts of individuals

- $\mathrm{H}_{10}$ - Perceived social empowerment of individuals positively related to perceived positive tourism impacts of individuals

- $\mathrm{H}_{11}$ - Perceived social empowerment of individuals positively related to residents support for tourism and related developments.

\subsection{Political Empowerment "Resident Empowerment through Tourism Scale (model)"}

Political empowerment generally referred to power for vote and participate in political activities. Yet, it encompasses the functions of voicing one's aspirations into collective actions. According to Scheyvens (1999, p. 247), the role of political empowerment in tourism context is to provide all community groups with a forum to raise concerns and questions about tourism development. (Boley, McGehee, Perdue, \& Long, 2014). " political empowerment, within a tourism context, increases residents perceptions of sociopolitical control; the extent to which individuals perceive themselves as having motivation and capacity to utilize social and political resources. Therefore, in a situation of empowering residents in tourism decision- making, it has a positive effect on overall community support for tourism. In real sense, as stated by (Sofield, 2003)" without active participation leading to political empowerment, locals "have inconvenience of tourism without economic advantages". In the main role of 
these resident attitudes research areas which collaborate with the dimensions of empowerment basically highlights their gaps such as empowerment remains central to community participation (Cole, 2006) versus the empowerment is poorly linked to residents' active participation in tourism and ultimately their response for tourism. Thus, there is no universally agreed conception on the role of political empowerment and its role in residents' tourism related behavior. Based on this account it is proposed

- H12 - Residents' perceived political empowerment is negatively related to their perceived negative tourism impacts

- H13 - Residents' perceived political empowerment is positively related to their perceived positive tourism impacts

- H14 - Residents' perceived political empowerment is positively related to their support for tourism and related activities

\subsection{Resident Empowerment through Tourism Scale (RETS)}

As a result in approaching all these dimensions, Boley and McGehee developed resident empowerment through tourism scale (RETS). This scale has subsequently been used as a tool to predict residents' support for tourism development together with their perceived economic benefits. RETS application is a promising tool in tourism research and "the ability to measure and track resident perceptions of empowerment is important for the industry for two main reasons. This application of RETS within the combined Weber/SET theoretical perspective answers (Nunkoo \& So, 2016) charge to develop new theoretical concepts to capture the complex attitudes and behaviors of residents toward tourism. Additionally, the inclusion of the RETS as an antecedent to resident attitudes toward tourism would build off of the previous work done by (Beritelli \& Laesser, 2011) and (Ryan, 2002) who point out the importance power plays within tourism development" (Boley \& Mcgehee,2014). 


\subsection{Conceptual Framework and Hypothesis Development}

Figure 1: Proposed model on residents' empowerment and their support for tourism development.

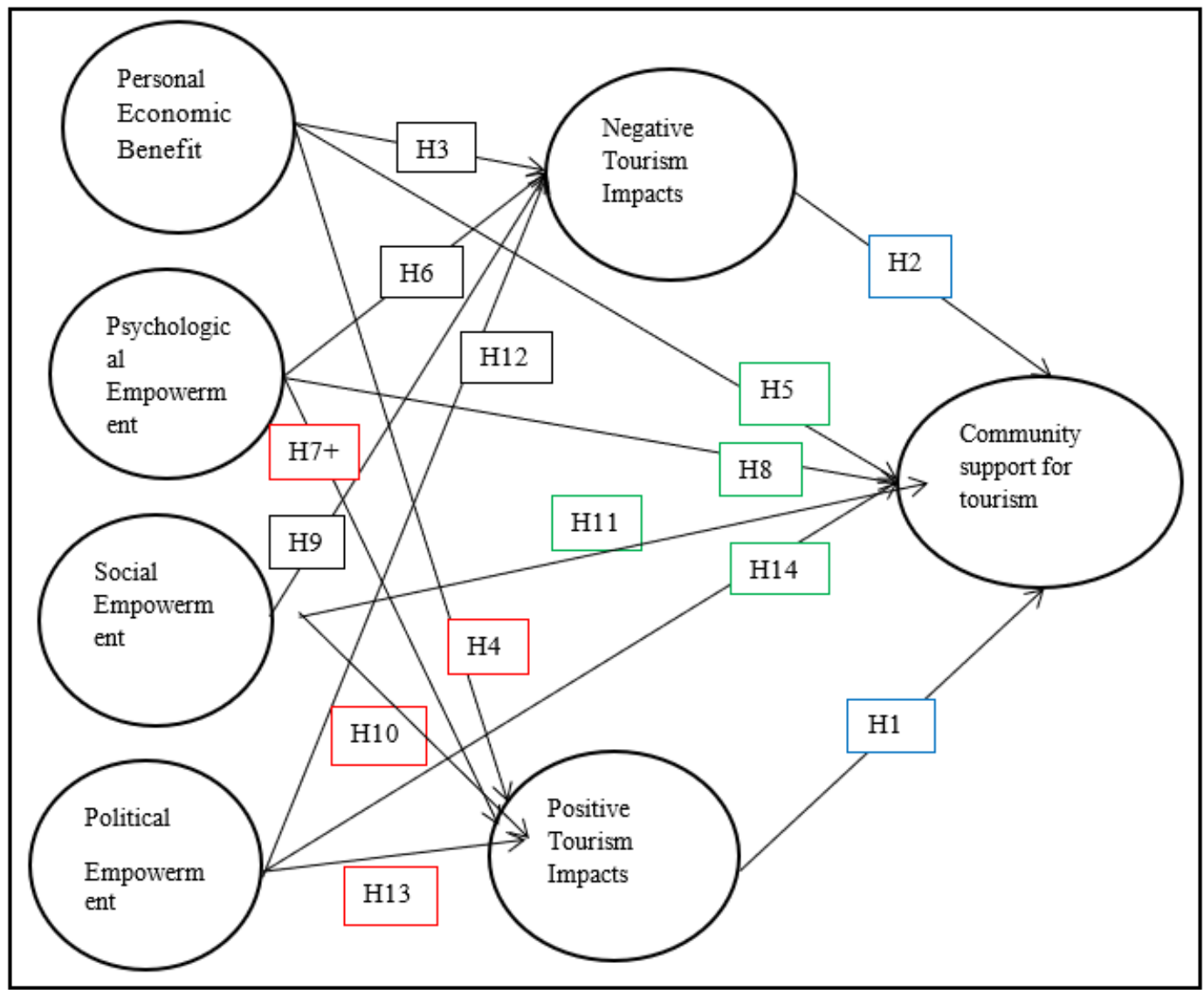

Source : Boley, McGehee, Perdue, Long 2014 , page 35

\section{Methodology}

\subsection{Measurements and Instrument}

The theoretical model with 14 hypotheses was proposed based on the literature. This study has adapted the RETS model originally proposed by Boley and McGehee, (2014). The model consists of seven constructs namely; psychological, social, political empowerment,negative tourism impacts,positive tourism impacts,community support for tourism that rooted originally from Boley and McGeehe's (2014), from recently developed RETS, with also the personal economic benefits from tourism adapted as a construct from Perdue et.al. (1990). These constructs were utilized in the RETS model, that was applied in the scales construction. The questionnaire is laid to its operationalization structures for data collection in RETS model and also in collecting information for hypothesis relationship analysis followed by the objectives of this research. The original questionnaire comprised section one with demographic analysis and then section two containing statements regard to 7 variable analysis, relevant to analysis of empowerment and attitudes which were present on a seven-point Likert scale 
( $1=$ strongly disagree, $7=$ strongly agree) to capture residents level of attitude towards tourism development in Kalpitiya. A pilot test was conducted in the same area with a sample of 49 respondents. The questionnaire was reworded and adjusted to enhance the efficiency based on the implications of reliability test results. Phase validity of the instrument was ensured by validating the finalized tool through 3 tourism professors.

\subsection{Population, Sampling and Data Collection}

The population of this study is the resident community in Kalpitiya tourism development zone, locates in Puttalam District in North Western Province of Sri Lanka. Primary data was collected through a door-to-door pen and paper survey and a selfadministered questionnaire was fielded for this purpose. Respondents were randomly selected from sampling frame where it varies in three Grama Niladari (GN) Divisions within Kalpitiya tourism zone as specified in Sri Lanka Tourism Act, No 2007. A total of 630 residents were surveyed from June to August 2018. Of the total 619 responses were valid for the final analysis with a 98 percent accuracy rate. In the aspects of data collection and analysis, the researcher potentially met with studies limitations of unwillingness of informants to fill the questionnaire due to language inaccuracy, comparison between qualitative analysis usage, time sequential gaps and most essentially limiting to a one framework of RETS throughout the study.

\subsection{Data Analysis}

Partial Least Square (PLS) path modeling method (Hair et al., 2013) was used to test the proposed model applying tool SmartPLS3 (Ringle, Wende, \& Will, 2005). PLS, as opposed to covariance-based SEM techniques, was preferred given its robust component-based approach which avoids estimation and identification issues. PLS handles comparatively smaller samples and has less restrictive assumptions on normality of data distribution. Most importantly our study focusing theory building on residents' support for tourism development PLS has shown promising applicability in it. It is equally suitable for theory building, theory extension and predictive applications (Hair et al. 2013; Hair, Ringle \& Sarstedt, 2015).

\subsection{Data Screening and Preparation for PLS-SEM}

In order to handle potential measurement problems, we conducted preliminary examination and analysis of data. The results showed that the data were suitable for PLS-SEM confirming the reliability and unidimensionality of measurement scale. According to Chin, (2010) and Hair et al., (2011) the thumb of rule for PLS path modeling is 1 to 10 times of arrows pointed to a variable in the model. Given the six arrows in our model, the rule demands only a sample of 60 cases where we have a sample of well above the minimum requirement. The Kaiser-Meyer-Olkin (KMO) value was $(\mathrm{KMO}=0.908)$, confirming sampling adequacy for the test. Bartlett's test of sphericity was significant $\left(\mathrm{X}^{2}=20797.574, \mathrm{p}<0.001\right)$ conforming item correlation standards required for the analysis. 


\subsection{Methodology Limitations}

As the specific limitations associated with the survey method can be depicted as the lack of richness in the data collected in a rural location that came through communication difficulties and relative potential biased introduced by the scale adapted while also the unwillingness of informants to complete questionnaire accurately. As another limitation, it is questionable that the methodological decision to investigate the research questions using quantitative analysis is better rather than qualitative analysis. Lack of the uasage of other variables and only limiting to the framework of RETS model could have been an effect to some extent in this study where more other factors could have been identified if to utilize these variables as well in the study.

\section{Results and Discussion}

\subsection{Demographic Profile of the Respondents}

Table1. Demographic Profile of the Respondents

\begin{tabular}{|c|c|c|c|}
\hline Variable & Group & Count & Percentage $\%$ \\
\hline \multirow[t]{2}{*}{ Gender } & Male & 251 & 40.5 \\
\hline & Female & 368 & 59.5 \\
\hline \multirow[t]{4}{*}{ Ethnicity } & Sinhala & 388 & 62.7 \\
\hline & Tamil & 170 & 27.5 \\
\hline & Muslim & 54 & 08.8 \\
\hline & Other & 7 & 01.1 \\
\hline \multirow[t]{4}{*}{ Age } & Below 24 & 216 & 34.9 \\
\hline & $24-35$ & 209 & 33.8 \\
\hline & $35-54$ & 179 & 28.9 \\
\hline & Above 54 & 15 & 02.5 \\
\hline \multirow[t]{4}{*}{ Education Level } & Secondary School & 403 & 65.1 \\
\hline & University/College & 33 & 05.3 \\
\hline & Graduate Degree & 35 & 05.6 \\
\hline & Other & 148 & 23.9 \\
\hline \multirow{2}{*}{$\begin{array}{l}\text { He or his family } \\
\text { work for tourism } \\
\text { industry }\end{array}$} & Yes & 314 & 50.7 \\
\hline & No & 305 & 49.3 \\
\hline \multirow{2}{*}{$\begin{array}{l}\text { Do they earn } \\
\text { income from } \\
\text { tourism }\end{array}$} & Yes & 179 & 28.9 \\
\hline & No & 440 & 71.1 \\
\hline \multirow[t]{4}{*}{$\begin{array}{l}\text { Knowledge } \\
\text { regarding industry }\end{array}$} & $\begin{array}{l}\text { Not at all } \\
\text { knowledgeable }\end{array}$ & 54 & 08.8 \\
\hline & $\begin{array}{l}\text { Somewhat } \\
\text { knowledgeable }\end{array}$ & 239 & 38.7 \\
\hline & $\begin{array}{l}\text { Moderately } \\
\text { knowledgeable }\end{array}$ & 238 & 38.4 \\
\hline & Very knowledgeable & 87 & 14.1 \\
\hline
\end{tabular}

Source : Author's own survey data of the study 
Overall detail describes the sample was moderately rich with more female respondents $(59 \%)$ than the males $(40.5 \%)$, which more ethnically represent Sinhalese (62\%) among other main ethnic groups. 34.9 percent respondents belong to the age group of below 24 years while smaller proportion indicated from the upper age group. The education levels of the sample seems to depend more on secondary education $(65 \%)$ with less priority for colleges and university education also with graduates $(10 \%)$. As for earners for tourism industry, $(50 \%)$ it is very week feature that although the amount engaged in tourism industry is quite better the income generated are lesser reporting $(28 \%)$.

\subsection{Evaluation of the Measurement Model}

Table 2. Cross Loadings

\begin{tabular}{|c|c|c|c|c|c|c|c|}
\hline & NIT & PEB & PIT & POE & PSY & SE & SFT \\
\hline NI1 & 0.8276 & 0.4487 & 0.5882 & 0.5932 & 0.424 & 0.3822 & 0.6019 \\
\hline NI2 & 0.7922 & 0.4121 & 0.5727 & 0.4553 & 0.4578 & 0.398 & 0.5254 \\
\hline NI3 & 0.788 & 0.4502 & 0.5527 & 0.5089 & 0.424 & 0.2997 & 0.5298 \\
\hline NI4 & 0.5116 & 0.2393 & 0.3174 & 0.2079 & 0.2522 & 0.1309 & 0.3439 \\
\hline PEB1 & 0.2393 & 0.5841 & 0.2207 & 0.2694 & 0.2358 & 0.1194 & 0.2722 \\
\hline PEB2 & 0.429 & 0.805 & 0.3797 & 0.3016 & 0.3152 & 0.3107 & 0.3885 \\
\hline PEB3 & 0.5278 & 0.8656 & 0.5488 & 0.4466 & 0.4948 & 0.3558 & 0.5933 \\
\hline PEB4 & 0.2841 & $\mathbf{0 . 6 3 2 9}$ & 0.3274 & 0.2554 & 0.2716 & 0.2775 & 0.2485 \\
\hline PI1 & 0.4567 & 0.4214 & 0.7341 & 0.4978 & 0.4735 & 0.4218 & 0.5118 \\
\hline PI3 & 0.4483 & 0.3377 & $\mathbf{0 . 6 3 5 3}$ & 0.3192 & 0.3171 & 0.2991 & 0.3402 \\
\hline PI4 & 0.5546 & 0.4221 & 0.7519 & 0.4863 & 0.4066 & 0.377 & 0.5517 \\
\hline PI6 & 0.5169 & 0.3754 & $\mathbf{0 . 7 0 3 5}$ & 0.4388 & 0.4288 & 0.3184 & 0.47 \\
\hline PI8 & 0.4982 & 0.3403 & 0.6495 & 0.3436 & 0.4203 & 0.3261 & 0.4481 \\
\hline PI9 & 0.3417 & 0.2326 & 0.5499 & 0.2023 & 0.2507 & 0.2189 & 0.3312 \\
\hline POE1 & 0.6352 & 0.4481 & 0.54 & 0.9097 & 0.5704 & 0.4932 & 0.5776 \\
\hline POE3 & 0.4635 & 0.3462 & 0.5024 & 0.869 & 0.5053 & 0.4524 & 0.5087 \\
\hline PSYE2 & 0.3289 & 0.3078 & 0.3044 & 0.3757 & 0.6874 & 0.3496 & 0.3765 \\
\hline PSYE3 & 0.4911 & 0.4174 & 0.4832 & 0.4969 & 0.7911 & 0.3578 & 0.5388 \\
\hline PSYE4 & 0.2951 & 0.2382 & 0.3678 & 0.3696 & 0.6523 & 0.2823 & 0.2792 \\
\hline PSYE5 & 0.3726 & 0.3596 & 0.4661 & 0.464 & 0.711 & 0.4476 & 0.4136 \\
\hline SE1 & 0.4661 & 0.3868 & 0.522 & 0.5501 & 0.4894 & 0.9286 & 0.5021 \\
\hline SE2 & 0.2183 & 0.1559 & 0.1912 & 0.246 & 0.2738 & 0.6706 & 0.2329 \\
\hline SE3 & 0.1122 & 0.2277 & 0.2485 & 0.2514 & 0.287 & 0.514 & 0.1625 \\
\hline SFT1 & 0.6316 & 0.5112 & 0.5977 & 0.5054 & 0.4149 & 0.4181 & $\mathbf{0 . 7 9 8 5}$ \\
\hline SFT2 & 0.581 & 0.4195 & 0.5682 & 0.5384 & 0.5269 & 0.3881 & 0.835 \\
\hline SFT3 & 0.3815 & 0.3698 & 0.4368 & 0.3185 & 0.3793 & 0.2147 & 0.669 \\
\hline SFT4 & 0.465 & 0.3718 & 0.4135 & 0.4789 & 0.4512 & 0.3894 & 0.7388 \\
\hline
\end{tabular}

Note: NIT-Negative impacts of tourism, PEB-Personal economic benefits, PIT-Positive impacts of tourism, POE-Political empowerment, PSY-Psychological empowerment, SE-Social Empowerment, SFTSupport for Tourism

Source : Author's own survey data of the study

Table 3. Results analyzed with CFA 


\begin{tabular}{|c|c|c|c|c|c|c|}
\hline Constructs & $\mathbf{C R}$ & Item & Mean & $\begin{array}{l}\text { Std. } \\
\text { Dev. }\end{array}$ & Loadings & $\begin{array}{l}T \\
\text { Statistics }\end{array}$ \\
\hline \multirow[t]{4}{*}{$\begin{array}{l}\text { Negative Impacts } \\
\text { of Tourism }\end{array}$} & \multirow[t]{4}{*}{0.825} & $\begin{array}{l}\text { Tourist increase lead to } \\
\text { friction between } \\
\text { residents and tourists }\end{array}$ & 0.8226 & 0.0374 & 0.8276 & 22.11 \\
\hline & & $\begin{array}{l}\text { Tourism cause } \\
\text { overcrowding }\end{array}$ & 0.7933 & 0.046 & 0.7922 & 17.23 \\
\hline & & $\begin{array}{l}\text { Increased cost of } \\
\text { living }\end{array}$ & 0.7847 & 0.0406 & 0.788 & 19.39 \\
\hline & & Garbage and littering & 0.5098 & 0.0768 & 0.5116 & 6.65 \\
\hline \multirow{4}{*}{$\begin{array}{l}\text { Personal } \\
\text { Economic Benefit } \\
\text { from Tourism }\end{array}$} & \multirow[t]{4}{*}{0.817} & $\begin{array}{l}\text { Tourism helps me pay } \\
\text { my bills }\end{array}$ & 0.5811 & 0.089 & 0.5841 & 6.56 \\
\hline & & $\begin{array}{l}\text { Portion of my income } \\
\text { is tied to tourism }\end{array}$ & 0.7997 & 0.0411 & 0.805 & 19.58 \\
\hline & & $\begin{array}{l}\text { Economically benefit } \\
\text { from more tourism } \\
\text { development }\end{array}$ & 0.8657 & 0.0234 & 0.8656 & 37.00 \\
\hline & & $\begin{array}{l}\text { Family's economic } \\
\text { future depends upon } \\
\text { tourism }\end{array}$ & 0.6188 & 0.0803 & 0.6329 & 7.88 \\
\hline \multirow[t]{4}{*}{$\begin{array}{l}\text { Positive Impacts of } \\
\text { Tourism }\end{array}$} & \multirow[t]{4}{*}{0.831} & $\begin{array}{l}\text { Tourism improves the } \\
\text { physical appearance }\end{array}$ & 0.7322 & 0.0532 & 0.7341 & 13.80 \\
\hline & & $\begin{array}{l}\text { Increases the number } \\
\text { of recreational } \\
\text { opportunities for local } \\
\text { homeowners }\end{array}$ & 0.6466 & 0.0608 & 0.6353 & 10.44 \\
\hline & & $\begin{array}{l}\text { Helps preserve the } \\
\text { cultural identity and } \\
\text { restoration of historic } \\
\text { buildings }\end{array}$ & 0.7517 & 0.0486 & 0.7519 & 15.47 \\
\hline & & $\begin{array}{l}\text { Contributes to income } \\
\text { and standard of living }\end{array}$ & 0.6951 & 0.0559 & 0.7035 & 12.57 \\
\hline
\end{tabular}




\begin{tabular}{|c|c|c|c|c|c|c|}
\hline & & $\begin{array}{l}\text { improves the local } \\
\text { economy }\end{array}$ & 0.6392 & 0.0696 & 0.6495 & 9.33 \\
\hline & & $\begin{array}{l}\text { Incentives for } \\
\text { protection and } \\
\text { conservation of natural } \\
\text { resources }\end{array}$ & 0.5408 & 0.0747 & 0.5499 & 7.35 \\
\hline \multirow[t]{2}{*}{$\begin{array}{l}\text { Political } \\
\text { Empowerment }\end{array}$} & \multirow[t]{2}{*}{0.883} & $\begin{array}{l}\text { have a voice in tourism } \\
\text { development decisions }\end{array}$ & 0.9102 & 0.0194 & 0.9097 & 46.85 \\
\hline & & $\begin{array}{l}\text { My vote makes a } \\
\text { difference in how } \\
\text { tourism is developed }\end{array}$ & 0.8653 & 0.0335 & 0.869 & 25.96 \\
\hline \multirow[t]{4}{*}{$\begin{array}{l}\text { Psychological } \\
\text { Empowerment }\end{array}$} & \multirow[t]{4}{*}{0.803} & $\begin{array}{l}\text { proud to be a resident } \\
\text { here }\end{array}$ & 0.6811 & 0.0589 & 0.6874 & 11.66 \\
\hline & & $\begin{array}{l}\text { feel special because } \\
\text { people travel to see my } \\
\text { area's unique features }\end{array}$ & 0.7875 & 0.0427 & 0.7911 & 18.53 \\
\hline & & $\begin{array}{l}\text { Reminds me that I have } \\
\text { a unique culture to } \\
\text { share with visitors }\end{array}$ & 0.6464 & 0.0684 & 0.6523 & 9.54 \\
\hline & & $\begin{array}{l}\text { Makes me want to tell } \\
\text { others about what we } \\
\text { have to offer }\end{array}$ & 0.7042 & 0.0634 & 0.711 & 11.20 \\
\hline \multirow[t]{3}{*}{$\begin{array}{l}\text { Social } \\
\text { Empowerment }\end{array}$} & \multirow[t]{3}{*}{0.758} & $\begin{array}{l}\text { Makes me feel more } \\
\text { connected to my } \\
\text { community }\end{array}$ & 0.9282 & 0.0204 & 0.6874 & 45.50 \\
\hline & & $\begin{array}{l}\text { Fosters a sense of } \\
\text { 'community spirit' } \\
\text { within me }\end{array}$ & 0.6646 & 0.0703 & 0.7911 & 9.54 \\
\hline & & $\begin{array}{l}\text { Provide ways for me to } \\
\text { get involved in my } \\
\text { community }\end{array}$ & 0.5003 & 0.1048 & 0.6523 & 4.90 \\
\hline \multirow[t]{4}{*}{$\begin{array}{l}\text { Support For } \\
\text { Tourism } \\
\text { Development }\end{array}$} & \multirow[t]{4}{*}{0.846} & $\begin{array}{l}\text { positive benefit of } \\
\text { tourism outweigh } \\
\text { negative impacts }\end{array}$ & 0.7911 & 0.0517 & 0.7985 & 15.44 \\
\hline & & $\begin{array}{l}\text { tourism should be } \\
\text { actively encouraged }\end{array}$ & 0.8335 & 0.0311 & 0.835 & 26.84 \\
\hline & & $\begin{array}{l}\text { I support tourism and } \\
\text { want to see it remain } \\
\text { important }\end{array}$ & 0.6674 & 0.066 & 0.669 & 10.13 \\
\hline & & $\begin{array}{l}\text { tourism zone should } \\
\text { support the promotion } \\
\text { of tourism }\end{array}$ & 0.7342 & 0.0511 & 0.7388 & 14.45 \\
\hline
\end{tabular}

Source : Author's own survey data of the study 
RETS originally consisted of thirty-two items across basic dimensions of empowerment. The outer loadings of the refined model eliminated fourteen items which were not satisfactory. Alpha values of SFT, PEB, and PI are high and above 0.7 confirming they are internally consistent for the test. Relatively the other constructs of PSY, SE, and POE and NI are also reaching their satisfactory levels above 0.6 with moderate reliability. CR values of the constructs ranging from 0.803 for the "Psychological Empowerment" to 0.883 for the "Political Empowerment". These seven measures all suggest that the constructs of the model have strong internal consistency, with values above the recommended value of 0.7 . It shows the items used to represent the constructs have satisfactory internal consistency within the model. The model depicts satisfactory indicator reliability when each item's loading is at least 0.5 and significant at 0.05. All constructs have AVE ranging from 0.507 to 0.791 , which exceeded the recommended threshold value of 0.5 with an exception to positive impacts of tourism indicating measurement model's convergent validity. Internal consistency and discriminant validity were measured and all the loadings showed strong construct reliabilities (above 0.6) indicating strong factor loadings with AVE above 50\%. Model indicated seven constructs reliable depicting empowerment in different context by contributing to the "field of empowerment which previously was only a conceptual idea without empirical measure" (Cole 2006 as cited in Boley and McGehee, 2014).

\subsection{Evaluation of Structural Model and Hypotheses Testing}

Table 4. Analysis on the path significant

\begin{tabular}{|c|c|c|c|c|}
\hline Hypotheses & Hypothesized Relationship & $\begin{array}{l}\text { Path } \\
\text { Coefficien } \\
\mathrm{t}\end{array}$ & $\begin{array}{l}\text { Standardized } \\
\text { T statics }\end{array}$ & Status \\
\hline H1 & $\begin{array}{l}\text { Positive Impacts } \rightarrow \text { Support for } \\
\text { Tourism }(+)\end{array}$ & 0.285 & 4.440 & Supported \\
\hline $\mathrm{H} 2$ & $\begin{array}{l}\text { Negative Impacts } \rightarrow \text { Support for } \\
\text { Tourism (-) }\end{array}$ & 0.210 & 3.288 & $\begin{array}{l}\text { Not } \\
\text { supported }\end{array}$ \\
\hline $\mathrm{H} 3$ & $\begin{array}{l}\text { Personal Economic Benefit } \\
\rightarrow \text { Negative Impacts (-) }\end{array}$ & 0.275 & 5.107 & $\begin{array}{l}\text { Not } \\
\text { supported }\end{array}$ \\
\hline $\mathrm{H} 4$ & $\begin{array}{l}\text { Personal Economic Benefit } \\
\rightarrow \text { Positive Impacts }(+)\end{array}$ & 0.143 & 4.711 & Supported \\
\hline $\mathrm{H} 5$ & $\begin{array}{l}\text { Personal Economic Benefit } \\
\rightarrow \text { Support for Tourism (+) }\end{array}$ & 0.143 & 2.633 & Supported \\
\hline H6 & $\begin{array}{l}\text { Psychological Empowerment } \\
\rightarrow \text { Negative Impacts (-) }\end{array}$ & 0.148 & 2.258 & $\begin{array}{l}\text { Not } \\
\text { supported }\end{array}$ \\
\hline $\mathrm{H} 7$ & $\begin{array}{l}\text { Psychological Empowerment } \\
\rightarrow \text { Positive Impacts }(+)\end{array}$ & 0.229 & 4.514 & Supported \\
\hline H8 & $\begin{array}{l}\text { Psychological Empowerment } \\
\rightarrow \text { Support for Tourism }(+)\end{array}$ & 0.127 & 2.284 & Supported \\
\hline H9 & $\begin{array}{l}\text { Social Empowerment } \rightarrow \text { Negative } \\
\text { Impacts (-) }\end{array}$ & 0.041 & 1.014 & $\begin{array}{l}\text { Not } \\
\text { supported }\end{array}$ \\
\hline $\mathrm{H} 10$ & $\begin{array}{l}\text { Social Empowerment } \rightarrow \text { Positive } \\
\text { Impacts }(+)\end{array}$ & 0.145 & 2.662 & Supported \\
\hline H11 & $\begin{array}{l}\text { Social Empowerment } \rightarrow \text { Support } \\
\text { for Tourism }(+)\end{array}$ & 0.050 & 1.287 & $\begin{array}{l}\text { Not } \\
\text { supported }\end{array}$ \\
\hline
\end{tabular}




\begin{tabular}{|l|l|l|l|l|}
\hline H12 & $\begin{array}{l}\text { Political Empowerment } \\
\rightarrow \text { Negative Impacts (-) }\end{array}$ & 0.389 & 6.927 & $\begin{array}{l}\text { Not } \\
\text { supported }\end{array}$ \\
\hline H13 & $\begin{array}{l}\text { Political Empowerment } \\
\rightarrow \text { Positive Impacts (+) }\end{array}$ & 0.254 & 4.208 & Supported \\
\hline H14 & $\begin{array}{l}\text { Political Empowerment } \\
\rightarrow \text { Support for Tourism (+) }\end{array}$ & 0.145 & 2.454 & Supported \\
\hline
\end{tabular}

Source : Author's own survey data of the study

Hypotheses one and two revels the relationship as H1 (Perceived positive impact of tourism is positively related with residents support for tourism $(\beta=0.285, t=4.440, P$ $<0.001)$ ), $\mathrm{H} 2$ (Perceived negative impact of tourism is negatively related with residents support for tourism $\beta=0.210, \mathrm{t}=3.288, \mathrm{P}<0.001$ ) highlighting positive and negative perceptions of impacts that create a response in resident community to support tourism development as explained and predicted in many previous researches of resident attitude in tourism models as (Perdue 1990) Andereck and Vogt 2000)Gursoy 2002,McGehee and Andereck 2004 ,Boley 2014) In this study H1 was supported by data and confirm in model depicting its significant positive relationship in paths "Positive Impacts ,"Support For Tourism Development" But $\mathrm{H} 2$ does failed to confirm its depiction and although its significant, the statistical evidence state their relationship is positive (Negative Impacts and Support For Tourism Development.) Though SET implied to accommodate the function of positive and negative impacts of tourism and with RETS model, including Webber's theory. The study predicts that they only concern benefits of tourism and more favorably they view impacts positively but not, view negatively in a way they are more economically, and empower motivated to support tourism development.

The economic constructs in model constructed three hypothesis (H3, H5), and only $\mathrm{H} 4$ and $\mathrm{H} 5$ were supported the analysis where it highlights importance of significant positive relation between Positive Impact and Personal Economic Benefits and also the relation between Support for tourism development and Personal Economic Benefits. Purposefully it depicts the more benefits residents earn from economic capability a destination produce through tourism with factors like "tourism help pay my bills", importantly feel them likely to see impacts favorably and support tourism development (Boley, Perdue, and McGehee). Findings of the three hypothesis testing relate to psychological empowerment $(\mathrm{H} 6-\mathrm{H} 8)$, which illustrate that the positive relationship between psychological empowerment and positive impacts and overall support for tourism are supportive in the study with significant relationship at $(\beta=0229$., $\mathrm{t}=4.514, \mathrm{P}<0.001, \beta=0.127, \mathrm{t}=2.284, \mathrm{P}<0.001)$ respectively.

But fairly proving (Andereck) idea of humans' engagement in non-market benefit, these people are empowered due to positive impacts of tourism in a context. Same to Kalpitiya. So, it is important that this findings highlights that developing tourism in a manner that locals are proud of their destinations uniqueness, they may more likely engage and support tourism in the area. Within the industry concerned with gaining local support, these findings prove that empowering residents psychologically as previous findings depict (Besculides, 2002, Boley and Perdue, 2014) through their willingness will strongly upscale tourism. Referred hypothesis to social empowerment (H9-H11), only one hypothesis (H10) was supported as, there is a significant positive relation between Positive Impacts and Social Empowerment with $(\beta=0.145$., $t=2.662$, $\mathrm{P}<0.001)$. These findings indicate how tourism impacts on positive functioning of residents within a society. If they feel that they are more connected to the community through tourism, they will view that tourism genera te positive effects and more impacts favorably, highlighting (Scheyvens, 1999) concepts of community cohesion. 
The hypotheses (H12-H14) illustrate political empowerment on the fact that only H13 and H14 were able to confirm the significant positive relationships between the paths. (Residents' perceived political empowerment is positively related to their support for tourism and related activities" was supported by the study. $(\beta=0.254$., $\mathrm{t}=4.208, \mathrm{P}<$ 0.001 ) and "Perceived political empowerment has a positive relationship with overall support for tourism" $(\beta=0.145$., $\mathrm{t}=2.454, \mathrm{P}<0.05)$ while $\mathrm{H} 12$ ("Perceived political empowerment has a negative relationship with perceived negative impacts from tourism" $(\beta=389$. $\mathrm{t}=6.927, \mathrm{P}<0.001)$ was failed to be confirmed. These findings depict the political empowerment enable them to view impacts favorably and support tourism conforming to previous findings Ramkisoon (2012).

\section{Discussion}

With illustration to the first research question, it is to measure and validate the previously constructed RETS model (Resident Empowerment through Tourism Scale). Although the development and exaggeration relate to the developed RETS model by Boley and McGehee at its initial stage, verification in wider and different context was an identified major issue in many earlier researchers relate to resident attitude. The findings endorse the use of non-economic constructs such as empowerment to predict resident support for tourism development (Nunkoo and Ramkisoon 2009). Among these factors, the strongest factor loadings shows by political empowerment, (POE1) which illustrate a loading of 0.909 depicting to be the most affected factor in the model. The constructs were reliable to depict empowerment in different context by contributing for the field of empowerment since the previous postulations on this were limited to only theoretical level. The models suitability in Kalpitiya, which is still developing, it indicates all positive hypotheses are significant rejecting negatively ordered hypothesis which only perceived positive impacts positively. Findings of this study revealed that residents of Kalpitiya tourism zone perceive that they are empowered psychologically and politically than socially. More importantly, the residents perceive the positive impacts and positive economic benefits of tourism in their perceived response to tourism and related activities. Additionally, the study depicts the way tourism is expected to developed, practiced and marketed in a community like Kalpitiya and where to focus if to achieve community contributions to the development.

\section{Conclusion and Contributions}

Local residents are an integral part of successful destination development. Thus, primarily, the aim of this study is to identify the impacts of residence community empowerment as a pivot in advocating residents' support for tourism development, examining the complex antecedents of residents' perceived positive or negative response for tourism development in a fast-growing tourist destination. This study strives to contribute to the tourism literature by extending the traditional impact driven model beyond the SET conventions. The study applies RETS for the prior objective and examines the other constructs such as social, psychological and political within the scope of empowerment.

This approach finds fitting since SET based economic rationalization restricts the elucidation of complex resident support for tourism development in their peripheries. Findings revealed more residents recognize themselves and believe that 
they are empowered politically and psychologically than socially and most relevantly with monetary benefits that they will view only positive impacts concerning only the benefits without overall cost analyses and response to support tourism in the area. Also, the study indicates that a tourism development that empowers residents can advocate their support and positive perception from residents.

The all positive relationships proposed are supported in the model where SET has highly been proven in the study context while all the negative relationships proposed are rejected. The study context being an emerging destination the community is eagerly looking for economic gains from tourism and their vigilance to negative impacts appears meager. The study also implies the necessity of tourism planners and managers responsibility to making sure that local community receive their economic stake to ensure their support for tourism. Equally, the positive significant relationships with empowerment endorses the theoretical perspectives of RETS. Thus the study supports to reject the conventional views that hold tourism development's success depends merely on economic functions in community. Thus, the study validates the connotation of empowerment, solidarity and emotional concerns of communities' in modeling their support for tourism. Thus, to ensure a sustained community support for tourism SET based economic rationalization is important while empowerment, solidarity, and emotional concerns are equally important.

\subsection{Theoretical Contributions}

Theoretically, this study reveals the utilization and understanding of the head theories of resident research (SET) "Stating that residents will evaluate tourism based upon the costs and benefits incurred to them through tourism ( McGeehe 2004). The imitations of SET leading to Weber's theory of formal and substantive rationality, capable of strengthen formal and substantive factor interpretation, not only financially but with benefits and costs of all factors inherent to describe the relationship and scale measurement in resident attitude field through established model (Boley and McGeehe, 2014). This study contributes to advance above theories into different contexts. The study validates the RETS model aligned with previous literature (Perdue 1990, Strzelecka 2016 and Boley 2014). This study support the developed model to be confirmed in broader global context expanding geographical cover of RETS. Theoretically, the findings extend the conventional views of SET by expanding RETS in an emerging destination context. The paper argues that mere SET approach is insufficient to explain the complex behavior of residents in supporting tourism development while empowerment acts as an agent to modify their decisions.

\subsection{Empirical Contributions}

This study contributes to the existing literature and confirms some of the previous postulations on residents' perceived response for tourism and related development in their peripheries particularly within the scope of empowerment. Precisely, the political, psychological and social empowerment of residents and their behavior toward tourism and related development was explained through the lenses of SET and RETS. Thus, the findings empirically enlighten the theoretical implications for empowerment and tourism development which is still at early stage of empirical 
investigation. Kalpitiya being one of the traditional fishing community, tourism and related developments have interfered their way of life and livelihoods. The findings of this study suggests that community empowerment can be used as a proxy to advocate tourism and related development in this context while promoting positive impacts of tourism to resident communities. This study contributes for effective decision making in the ongoing Kalpitiya tourism development project. The findings can be considered to empower residents in the tourism development process in making residents' advocacy and support for tourism in the long run.

\subsection{Future Research Directions}

This study is limited to the community empowerment and its role in advocating their support for tourism development. Future research could also examine factors affecting resident levels of empowerment particularly in destinations where initial tourism development is taking place. Further, the study sheds a light on resident empowerment through tourism while it can be influenced by various other factors. An examination on other factors that promote community empowerment and their role in predicting residents' behavior can be another area for future research. The use of empowerment and RETS application in the fields of sustainable tourism development could be a total separated and wider area that more researchers can be developed in future with also adapting to the modern tourism trends in the world. Moreover, resident community characteristics and their socio-demography were not incorporated in this study which may be a potential study for future researchers.

\section{References}

1. Aghazamani, Y., and Hunt, C. (2017). Empowerment in Tourism: A Review of Peer reviewed Literature. Tourism Review International, 21(4), 333-346.

2. Aghazamani, Y., and Hunt, C. (2017). Empowerment in Tourism: A Review of Peer-reviewed Literature. Tourism Review International, 21(4), 333-346.

3. Andereck, K., and Vogt, C. (2000). The Relationship between Residents' Attitudes toward Tourism and Tourism Development Options. Journal of Travel Research, 39(1), 27-36.

4. Androniceanu, Armenia (2019). The social sustainability of smart cities: urban technological innovation, big data management, and the cognitive internet of things, Geopolitics, History, and International Relations, 11(1),110-115. doi: 10.22381

5. Anon, (2018).Tourism Development in least developed countries. Retrieved March 27, 2018. from https://www.igi-global.com/chapter/tourismdevelopment-in-least-developed-countries/135811 
6. Bapr, A. (1980). Community Development and Minorities-Problems and Feasible Strategies. Community Development Journal, 15(3), 179-189.

7. Beeton, S. (2005). Empowerment for Sustainable Tourism Development. Annals of Tourism Research, 32(3), 820-822.

8. Besculides, A., Lee, M. E., and McCormick. (2002).Resident's Perception of the Cultural Benefits of Tourism. Annals of Tourism Research,29(2),303-319.

9. Boley, B., Ayscue, E., Maruyama, N., and Woosnam, K. (2016). Gender and Empowerment: Assessing Discrepancies using the Resident Empowerment through Tourism Scale. Journal of Sustainable Tourism, 25(1), 113-129.

10. Boley, B., Maruyama, N., and Woosnam, K. (2015). Measuring Empowerment in an Eastern Context: Findings from Japan. Tourism Management, 50, 112-122.

11. Boley, B., and McGehee, N. (2014). Measuring Empowerment: Developing and Validating the Resident Empowerment through Tourism Scale (RETS). Tourism Management, 45,85-94.

12. Boley, B., McGehee, N., Perdue, R., and Long, P. (2014). Empowerment and Resident Attitudes toward Tourism: Strengthening the Theoretical Foundation through a Weberian. Annals of Tourism Research, 49, 33-50. https://doi.org/10.1016/j.annals.

13.Boley, B., \& Perdue, R. R. (2012). Destination Management, Competitiveness, and Quality-of-Life: A review of Literature and Research Agenda. Handbook of Tourism and Quality-of-Life Research, 515-528. https://doi.org/10.1007/978-94007-2288-0_30

14. Butler, R. (1999). Sustainable Tourism: A state-of-the-art review. Tourism Geographies, 1(1), 7-25.

15. Carey, D. I. (1993). Development based on Carrying Capacity: A Strategy for Environmental Protection. Global Environmental Change, 3(2), 140-148.

16. Choguill, M. B. G. (1996). A Ladder of Community Participation for Underdeveloped Countries. Habitat International, 20(3), 431-444.

17. Choi, H. C., and Murray, I. (2010). Resident Attitudes toward Sustainable Community Tourism. Journal of Sustainable Tourism, 18(4), 575-594.

18. Choi, H. S. C., and Sirakaya, E. (2005). Measuring Residents' Attitude toward Sustainable Tourism, Development of Sustainable Tourism Attitude Scale. Journal of Travel Research, 43(4), 380-394.

19. Cole, S. (2006). Information and Empowerment: The keys to achieving sustainable tourism. Journal of Sustainable Tourism, 14(6), 629-644.

20. Cornell Empowerment Group. (1989). Empowerment and Family Support. Networking Bulletin, 1(2), 1-23.

21. Dogans, G., and Denny, G.R. (2004). Host Attitudes toward Tourism: An Improved Structural Model. Annals of Tourism Research, 31(3), 495516. https://doi.org/10.1016/j.annals

22. Emerson, R. M. (1976). Social Exchange Theory. Annual Review of Sociology, 2, 335-362.

23. Enders, C. K., and Bandalos, D. L. (2001). The relative performance of full information maximum likelihood estimation for missing data in structural equation models. Structural Equation Modeling, 8(3), 430-457.

24. Fetterman, D. (2018). Empowerment Evaluation's Roots in Community. New Directions for Evaluation, 2018(157), 87-88.

25. Friedmann, J. (1992). Empowerment: The Politics of Alternative Development. Cambridge: Blackwell. 
26. Gunapala, A. Residents' perceptions of tourism impacts and attitudes towards tourism policies. (n.d.). Retrieved March 27, 2018 from http://.academia.edu/AthulaGnanapala

27. Gunn, C. A. (1979). Tourism planning: New York: Crane, Russak \& Company.

28. Gursoy, D., Chi, C. G., and Dyer, P. (2010). Locals' Attitudes toward Mass and Alternative Tourism, The Case of Sunshine Coast, Australia. Journal of Travel Research, 49(3), 381-394.

29. Gursoy, D., Jurowski, C., and Uysal, M. (2002). Resident Attitudes: A Structural Modeling Approach. Annals of Tourism Research, 29(1), 79-105.

30. Hidayat, A., Rahmanita, M., and Hermantoro, H. (2017). Community Empowerment in Plempoh Cultural Tourism Village. TRJ Tourism Research Journal, 1(1), 98.

31. Hur, M. H. (2006). Empowerment in Terms of Theoretical Perspectives: Exploring a Typology of the Process and Components across Disciplines. Journal of Community Psychology, 34(5), 523-540.

32. Hussain, A. and Endut, N. (n.d.). Application of SEM using Smart PLS.

33. Kalpitiya Development. (2018). Retrieved March 26, 2018, from http://www.bing.com/Kalpitiya_development

34. Kaplan, D. (2000). Structural equation modeling. Thousand Oaks, Calif.: Sage Publications.

35. Lee, T. H. (2013). Influence analysis of community resident support for sustainable tourism development. Tourism Management, 34, 37-46.

36. Marzuki, A. and Khoo, J. (2016). Community Development Strategies for Tourism Development in Langkawi Islands, Malaysia. Tourism - From Empirical Research Towards Practical Application.

37. May, V. (1991). Tourism,Environment, and Development. Tourism Management, 12(2), 112-118.

38. McGehee, G., and Andereck, k. (2004). Factors Predicting Rural Residents' Support of Tourism. Journal of Travel Research, 43 (2), 131-140. https://doi.org/10.1177/0047287504268234

39. Moore, C.V. (December 10, 2012). Tourism Plays Vital Role in Fayette County. Fayette Tribune. Retrieved $29^{\text {th }}$ July 2013 from http://www.fayettetribune.com

40. Mura, L., Ključnikov, A. (2018). Small Businesses in Rural Tourism and Agrotourism: Study from Slovakia. Economics \& Sociology, 11(3),286-300.

41. National Geographic Center for Sustainable Destinations. (2013). National Geographic Center for Sustainable Destinations. Retrieved from http://travel.nationalgeographic.com

42. Nunkoo, R., and So, K. (2016). Residents' Support for Tourism. Journal of Travel Research, 55(7), pp.847-861.

43. Pellešová, P., Kajzar, P. (2017). A tourism and selected tourist facilities in the Czech republic and Republic of Belarus. Acta Oeconomica Universitatis Selye 6 (1), $99-112$.

44. Ranasinghe. R. (2019). Determinants of Tourist Loyalty: an extended structural equation model from post-war tourism development context in Sri Lanka. Journal of Management and Tourism Research. 1 (1), 95-113.

45. Ranasinghe. R., (2018). Cultural and Heritage Tourism Development in Postwar Regions: Concerns for Sustainability from Northern Sri Lankan Capital Jaffna. Journal of Tourism and Recreation, 4. (1), 1-18. 
46. Reliability Analysis. Retrieved from http://tx.liberal.ntu.edu.tw/Data Analysis

47. Sadan, E. (1997). Empowerment and Community Planning. Tel-Aviv: Hakibbutz Hameuhad (Hebrew). Retrieved from http://www.mpow.org

48. Sadan, E. (2004). Empowerment and Community Planning. [Publisher not identified].

49. Scheyvens, R. (1999). Ecotourism andTthe Empowerment of Local Communities. Tourism Management, 20(2), 245-249.

50. Simionescu, M. (2016). Competitiveness and Economic Growth in Romanian Regions. Journal of Competitiveness, 8(4), $46-60 . \quad$ DOI: 10.7441/joc.2016.04.03

51. Sofield, T. (2003). Empowerment for Sustainable Tourism Development. London: Pergamum.

52. Sri Lanka Tourism Development Authority (2018) | Sri Lanka Tourism Development Authority. Retrived27th March 2018 from http://www.sltda.lk/index.php

53. Strzelecka, M., Boley, B. and Strzelecka, C. (2016). Empowerment and Resident Support for Tourism in Rural Central and Eastern Europe (CEE): the Case of Pomerania, Poland. Journal of Sustainable Tourism, 25(4), 554-572.

54. Sutawa, G. (2012). Issues on Bali Tourism Development and Community Empowerment to Support Sustainable Tourism Development. Procedia Economics and Finance, 4, 413-422.

55. Wolf, M., Albinsson, P. and Becker, C. (2015). Do-It-Yourself Projects as Path toward Female Empowerment in a Gendered Market Place. Psychology \& Marketing, 32(2),

56. Woosnam, K., Norman, W., and Ying, T. (2009) Exploring the Theoretical Framework of Emotional Solidarity between Residents and Tourists. Journal of Travel Research, 48 (2), 245-258. https://doi.org/10.1177/0047287509332334

57. Yu, C. P., Cole, S. T., and Chancellor, C. (2018). Resident Support for Tourism Development in Rural Midwestern (USA) Communities: Perceived Tourism Impacts and Community Quality of Life Perspective Sustainability, 10(3), 802.

58. Zimmerman, M.A. (1995). Psychological empowerment: Issues and illustrations. American Journal of Community Psychology, 23(5), 581-599.

\section{Brief description of Author/Authors:}

\section{Authors name and titles}

Dr. Ruwan Ranasinghe

Head/Department of Tourism Studies, Faculty of Management, Uva Wellasa University of Sri Lanka, www.uwu.ac.lk, ruwan@uwu.ac.lk, ruwan.fm@gmail.com

Dr. Ranasinghe is presently heading the Department of Tourism Studies of Uva Wellassa University and is also the Director for Operations and Technical Scretariat of AHEAD World Bank project. He has over 20 perre reviwed research publications in indexed journals in the areas of tourism planing, destination management, hospitality management and tourist destination mobilities.

\section{Authors name and titles}

Jayathree Pradeepamali, Department of Tourism Studies, Faculty of Management, Uva Wellassa University, Badulla, Sri Lanka, jayathreepradeepamali@gmail.com 
Jayathri attached to the Department of Tourism studies of Uva Welassa University is presently reading for Master of Sustainable Tourism Managet at peradeniya university. Her main research areas are community based toursm, sustainable tourism Development and turist destination marketing and management. 